\title{
Interdisciplinary perspective-taking within argumentation: students' strategies across science and religious education
}

\author{
Nigel Fancourt $^{1}$ (D) $\cdot$ Liam Guilfoyle $^{1}$ (D)
}

Accepted: 31 August 2021 / Published online: 23 December 2021

(c) The Author(s) 2021

\begin{abstract}
The importance of developing students' argumentation skills is well established across the curriculum: students should grasp how claims are made and supported in different disciplines. One challenge is to follow and thereby agree with or critique the arguments of others, which requires perspective-taking, in tracing these other reasons and reasoning. This challenge is increased when disciplines construct argumentation and perspective-taking differently. Here, we consider the role of perspective-taking in argumentation within and between science education and pluralistic religious education, where the former aims at the justification of scientific claims and the latter at both an empathetic understanding of different religions and worldviews, and personal reasoning. We interpretively analyze student data to identify salient features of students' strategies to perspective-taking within argumentation. Data from 324 pupils across nine schools are explored in relation to students' challenges in perspective-taking, strategies for perspective-taking within argumentation, and the use of perspective-taking to construct personal argumentation. The analysis shows some barriers to perspective-taking within argumentation, the range of students' perspective-taking strategies within argumentation, and how personal argumentation could hermeneutically build upon perspective-taking strategies. The importance and implications of perspective-taking within argumentation across the curriculum are considered highlighting challenges in the etic/emic shift, both within the individual subject as well as across them, and some reflections on how this provides a fresh pedagogical perspective on the science/ religions debate are made. To end, we conclude with the wider challenges for disciplines and perspective-taking across schooling and university.
\end{abstract}

Keywords Argumentation · Education · Interdisciplinary · Perspective-taking · Religion · Science

Nigel Fancourt

nigel.fancourt@education.ox.ac.uk

1 Department of Education, University of Oxford, 15 Norham Gardens, Oxford OX2 6PY, UK 


\section{Introduction}

A common educational challenge internationally is ensuring that students leave school with both an understanding of various intellectual disciplines underpinning curriculum subjects and of fluid intellectual capacities that cross them. Students should be capable in religious education, mathematics, history or science, and capable of thinking across them, not simply as valuable intellectual capacities but also as vital attributes of informed, deliberative citizens. Resolving this puzzle has led in two directions: attention to the relationships between different disciplines and subjects, whether through cross-curricular approaches and overlapping topics, or interdisciplinary and transdisciplinary approaches; attention to broader holistic intellectual capacities, such as dialogue or-our foci here-argumentation and perspective-taking.

The two intellectual processes of argumentation and perspective-taking can be found across curricula internationally. First, the process of argumentation or reasoning is subjectspecific but also at least implicitly common across subjects, and curriculum planners have addressed this puzzle through the interweaving of a common language to describe elements of the curriculum or standards of attainment within the essential substantive subject knowledge. In Korea, curriculum documents stated that an aim of schooling is for students to 'be able to think, reason, and criticize in creative ways' (Ministry of Education, Science and Technology, 2008, p. 3); Sweden goes further in adopting a common language to describe curricular requirements, identifying the need for 'well developed and well informed reasoning' across most subjects, including chemistry, geography, history, and religion (Skolvokert, 2018, pp. 197, 207, 217, 227). There will inevitably be degrees of integration, and some countries prefer to treat subjects individually, but the question of integration is constant in curriculum design, and indeed can change in a country from one policy to the next.

Second, the value of perspective-taking - of thinking or feeling as someone else-is also found across the curriculum, though it is a "critical yet tangled construct that is used to describe a range of psychological processes and...is applied interchangeably with related constructs' (Kahn \& Zeidler, 2019, p. 605), including theory of mind and empathy. In history, empathy has long been valued, enabling students to enter into past worldviews (e.g., Endacott, 2014; Lee \& Ashby, 2001). In English and drama, students must grasp characters' personal perspectives both cognitively and affectively (e.g., Morrison, 1988; Gallagher et al., 2018). Its value is not simply academic; Nussbaum (2010) emphasises its importance within the humanities for moral education, in giving 'students the ability to see themselves as members of a heterogeneous nation.... and a still more heterogeneous world' (p. 80), thereby highlighting the fact of disagreement between people, both nationally and internationally, for an informed global citizenry. This dimension of perspective-taking is particularly important in pluralistic religious education, which focuses on students' impartial understanding of several religions or worldviews rather than on learning within a particular religious or philosophical tradition (Fancourt, 2014). Students in many countries have long been expected to adopt a perspective-taking approach to the theological, philosophical and ethical stances of different beliefs, often seen as a valuable part of intercultural citizenship education-in learning to live together (Franken \& Loobuyck, 2011; Jackson, 2014).

These two strands are both subject-specific and cross-curricular, so their inter-relationship is often complex. We explore this across science and religious education, drawing on data from a wider research project, the Oxford Argumentation in Religious and Science education project ('OARS') (Erduran et al., 2019; Chan et al., 2020; Erduran, 2020; 
Guilfoyle et al., 2020; Guilfoyle, Hillier \& Fancourt 2021). Science and religion can be seen as antithetical (e.g., Dawkins, 2006), and some argue that this also applies educationally (Mahner \& Bunge, 1996). Indeed, students do not come unknowingly to lessons that tackle this relationship, often having pre-existing opinions (Taber et al., 2011; Hoven, 2015; Pearce et al., 2019), so this interdisciplinary arena offers rich potential for exploring the interaction between argumentation and perspective-taking. However, this project is based in England, where an impartial study of different religions and worldviews prevails in religious education, thus avoiding some of the conventional science and religion debates (see Hanley et al., 2014), but also raising new questions about argumentation and perspective-taking. First then we consider the two strands theoretically before considering how they have been researched within education.

\section{Argumentation and perspective-taking: a theoretical comparison}

Argumentation and perspective-taking can be seen as separate but inter-related intellectual processes. The former, in the logical analysis of the justification of claims is as old as philosophy itself, but theories of argumentation only emerged explicitly in the late 20th Century, focusing on how criteria and processes can vary in different settings. For instance, Toulmin (1958) distinguished between field-dependent properties of argumentation, which pertained to the discipline or profession in question, and field-invariant properties, which were generic, applying across all forms of social argumentation, so that in presenting and considering different perspectives there would be both specific and general features of argumentation at stake. Other classifications have been proposed, for instance into formal and informal - with the latter being subdivided into rhetorical and dialectical forms (van Eemeren et al., 1996; see also Walton, 1996): formal argumentation is the realm of logical analysis, rhetorical argumentation is concerned with discursive, persuasive technique, and dialectical argumentation is when there is a disagreement between individuals who must consider and respond to others' arguments, thereby hinting at an element of perspective-taking.

Perspective-taking has also long been valued. Coleridge, in 1815, considered that 'our conceptions are imprisoned by the lines we have drawn to exclude the conceptions of others' (Coleridge, 1985, p. 288), highlighting the value of encountering different ways of thinking. Explicit recognition of the value of various forms of perspective-taking and empathy emerged in the late nineteenth and early twentieth centuries, notably in the philosophical phenomenology of Husserl (1931), and Scheler (1954). This intellectual capacity is considered of ethical worth (Pizarro et al., 2006; Roughley \& Schramme, 2018), as an ethics of care or fellow feeling, so that we can judge the effects on others of our actions, and our ethical thinking. It also has a cognitive strand, as a form of inter-human understanding, in seeking to immerse oneself within another's lifeworld, so that one can place oneself in their cognitive and experiential position 'bracketing out' one's own thoughts and feelings. This became significant in various branches of the social sciences, which separate the emic - what someone's own worldview is for them, from the inside-and the etichow social scientists externally classify or assess these worldviews.

There are challenges in combining argumentation and perspective-taking. At the risk of over-generalisation, they represent key methodological differences between the humanities and sciences. A central epistemic feature of scientific method is to strip out fellow-feeling (Morrison, 1988), requiring dispassionate observation of both the natural world and human 
behaviour, rather than imaginatively entering into others' thoughts or feelings, or attributing thoughts or emotions to the natural world. Scientific laws do not depend on what people think is occurring, but on what empirical data suggest. By contrast, the humanities often focus on the interpretation of meaning, whether in literature, history or cultures, and disciplinary forms of argumentation are often built upon this process. These challenges are compounded when the disciplines in question are not simply seen as different but seen as epistemically antithetical, as is the case in considering science and religion.

Argumentation and perspective-taking overlap in the consideration of someone else's argument because this requires being attentive to their precise claim and its justification, which is through taking their perspective. Most new arguments that we encounter are not of our own creation, but are presented to us by others, so that any assessment of another's argument usually requires an element of perspective-taking. To accept their argument is to agree with the construction of the argument and to critique it is to identify faults within it, whether evidential weakness, logical flaws, or qualifications, and both require an encounter with this other perspective. This can be framed as a hermeneutical problem, in that we must interpret the meanings that others present to us, with each element enabling us to develop a deeper understanding of their perspective. Gadamer (2004) conceptualised this process as the encounter of different horizons of understanding through a hermeneutical conversation, leading to a fusion of horizons. His concern was not whether an explicit line of reasoning along agreed principles was acceptable but how we begin to engage with other points-of-view. Hermeneutical encounter was therefore not about simply recreating another's thoughts through their words or text, as previous philosophers of hermeneutics, notably Schleiermacher (1977), had argued, rather it was about the oscillation between one's own thoughts and the thoughts of others. Argumentation demands that one appraises different perspectives against field-dependent or field-independent criteria, so that one is required to apply these criteria to the other's perspective.

\section{Argumentation and perspective-taking: research in religious education and science}

There does not appear to be any previous interdisciplinary research on both argumentation and perspective-taking in religious education. The closest example is Duveen and Solomon's (2007) account of role-playing a fictional blasphemy trial for Darwin, though this focused on historical empathy. However, there has long been research interest in argumentation more generally across science and religious education, especially around etiological and ethical issues (Fuchs, 2009; Basel et al., 2014; Weiß, 2016), around the broader epistemic differences (e.g., Billingsley et al., 2012; Pearce et al., 2019), or the challenges facing religious students or teachers (e.g., Dodick et al., 2010).

Research on argumentation and perspective-taking in science education and in pluralistic religious education respectively has burgeoned in recent decades, but these two avenues have followed inverse paths. Within research on religious education, the issue of perspective-taking, especially empathy, emerged in 1970s as a defining feature of pluralistic religious education, and subsequently an interest in argumentation emerged. Smart (1969) laid the intellectual foundations for perspective-taking; he established 'religious studies' in higher education, adopting a phenomenological approach to world religions, which drew on the emic/etic distinction between insiders' and outsiders' perspectives. He also 
contributed to curriculum development for the Schools Council (1971), which called for 'an empathetic experience of the faith of individuals and groups' (p. 21), in the context of an increasing religious diversity because of post-colonial immigration.

In 1990s, criticisms were increasingly voiced that, particularly in secondary schools, this approach was too descriptive, and pupils should engage with religions' truth claims. Various more critical models emerged that finetuned the place of empathy. Jackson (1997) questioned whether students could fully think themselves into another's beliefs, and Wright (1993) was wary of an implicit relativization of religious claims. Both called for elements of argumentation-though this term was not used-in developing pupils' skills in formulating their own opinions within an 'impartial' classroom (see Jackson \& Everington, 2017). However, a fundamental debate remains about the relevant academic discipline(s) within which to frame the subject. Indeed, some recent models ask pupils to adopt a range of different approaches, including participator and philosopher (Freathy \& John, 2019); this demands a different type of perspective-taking in that pupils should 'step in and out of character' (p. 237) for these different disciplinary perspectives. The challenge remains balancing the emic/etic divide, between insiders and outsiders, but with adopting the appropriate descriptive and normative academic lenses (Fancourt 2014), especially given the postsecular turn which repositions religion within the public sphere (O'Grady 2018; Franck \& Thalén 2021).

By contrast, in science education research, a focus on argumentation emerged initially and then interest in perspective-taking has arisen, particularly when considering socio-scientific issues. The process of argumentation —in substantiating a claim—is fundamental to science, so its emergence as an explicit focus of research from 1990s was unsurprising, particularly given increasing educational interest in nature of science and knowledge construction (e.g., Kuhn, 1991), in the socio-cultural dynamics of classrooms (e.g., Kelly \& Chen, 1999), and, from 2000s, in socio-scientific issues (e.g., Zeidler, 2003).

Increasing attention to socio-scientific issues encouraged research on perspective-taking because these issues raise complex scientific and ethical conundrums, in which close attention to others' arguments is essential, and because solutions are often through deliberative compromise and negotiation (Simmoneaux, 2007). Research has included studies of the effect of perspective-taking on reducing 'belief bias' (McCrudden et al., 2016, p. 1), and particularly on role-playing specific issues (Belova et al., 2015; Maniatakou et al., 2020). More recently, conceptual models of perspective-taking within argumentation on socio-scientific issues have been developed, linking perspective-taking in sciences with the humanities (Khan \& Zeidler, 2016, 2019; Newton \& Zeidler, 2020), as well as studies of students' challenges in perspective-taking (Acar et al., 2010).

These developments in two lines of research inevitably mirror changes in the curriculum, but which begs the question as to how students address such challenges; therefore our research aim is to consider how students approach perspective-taking within argumentation across science and religious education. It is phrased as an 'approach' to argumentation to indicate that they were neither simply arguing nor developing their own lines of argumentation, but to pay attention to the wider set of methods and strategies that were involved. The preposition 'within' highlights the fact that perspective-taking is not an end in itself, for literary or dramatic purposes, but is a strategy to support argumentation. 


\section{Methodology: an interpretive analysis}

As noted above, this paper is part of a research and development project on strategies for cross-curricular argumentation between science and religious education teachers in England (Erduran et al., 2019), drawing on Toulmin (1958) as a theoretical frame. This included assessing the effect of various interventions on students' argumentation skills within and across the two subjects, which required designing a cross-curricular test instrument (see "Appendix 1", described below), drawing on previous research instruments (Osborne et al., 2016), to calibrate students' skills in argumentation in science, religious education and on a cross-curricular topic. Another paper has presented the quantitative preintervention findings on argumentation from this instrument, from 324 students, aged 11 to 14 years old, from nine schools (Guilfoyle et al., 2021).

However, the process of scoring the test instruments for quantitative analysis afforded the opportunity to notice patterns in student responses and an opportunity to reflect on these students' responses as an interdisciplinary team of science and religious education educators and researchers. A sense of puzzlement (Oancea \& Pring, 2008) emerged in noticing such patterns, partly as our own different subject backgrounds seemed to lead to different priorities, and so here the analysis was a secondary process following our puzzlement around pupils' use of perspective-taking. Surveys are not an obvious choice of research instrument for data on perspective-taking, but we were struck by how pupils drew on it automatically within these controlled conditions; this puzzlement frames our own hermeneutical encounter, understood as a dialectical tension between Gadamerian horizons of understanding, ours in looking for categories of argumentation, and the pupils in identifying human characters.

This puzzlement led us to review wider literature (presented above) and as a result three research questions came to be posed:

- What are the challenges to students' perspective-taking within argumentation? This considers the limitations of or barriers to a hermeneutical encounter with the reasoning of others.

- What are students' strategies for perspective-taking within argumentation? This considers the different ways that students engaged with the arguments of others.

- How do students construct their own arguments based on perspective-taking? This question considers how students deploy the horizons of others in developing their own arguments.

The instrument from which the puzzlement emerged will now be described because this served also as the source of data for interpretive analysis to answer these questions.

\subsection{The instrument}

Within the test, three scenarios each presented two characters with differing views, so that students had to identify each individual's line of argumentation, i.e., following different perspectives, before being asked which they considered stronger or better, with the design drawing on Erduran et al. (2004). Typical etiological questions were avoided (e.g., Basel et al., 2013, 2014), and instead comprised of three scenarios: 'Christmas for nonChristians', addressing arguments over whether religious festivals should be celebrated 
by non-adherents to that faith; 'What's growing?' addressing the biological distinction between plants and fungi; 'A zoo near you', addressing the socio-scientific issue of the ethics of zoos, including the religious notion of stewardship (see Altmeyer, 2021). They are referred to as the Christmas, Stems and Zoos scenarios. The topics were checked against curriculum documents to ensure suitability.

The scenarios had a similar sub-question structure, working through identification of claim, nature of evidence, evidence and warrant, and ending with a personal expression of argumentation. The Christmas scenario posited 'Abdul', who argued from the analogy of considering Eid to be an exclusively Muslim festival to hold that only Christians should celebrate Christmas, with 'Miriam', who argued more inclusively, on grounds of fairness for mixed-belief households. The Stems scenario pitted 'Olga', who considered that growing things with stems were plants, against 'Eve', who thought they were fungi because they were growing in darkness, balancing visual evidence with biological taxonomy. The Zoo scenario contrasted 'Ahmed' who was in favour of zoos as sites for research and breeding with 'Charlotte', who considered that animals should only be in the wild. Students therefore were not simply presented with a different perspective to their own (McCrudden et al., 2016); instead, they were presented with two differing perspectives which they had to follow in order to decide with which they agreed. Perspective-taking was not simply oppositional, in having to consider a position that they did not agree with, but was a pre-condition of enabling them to decide whether they agreed with a particular perspective or not.

\subsection{Data analysis}

We adopted an interpretive analysis (Kerdeman, 2015) of the students' responses, and consider it a secondary analysis as it was not what the instrument was designed to address. Students' religious affiliations were unrecorded; most would probably be described as agnostic but culturally Christian, some would self-identify as Christian, and some as Muslim, particularly from two inner-city schools; other religions might also be represented. The schools included a range of state and private, secular and church-run; six offered pluralistic religious education, and two included the study of other religions within a confessional approach (Roman Catholic and Evangelical). We inductively explored how they reacted to and drew upon the six characters in answering the scenarios' questions, seeking hermeneutically to adopt our own perspective-taking on the students' perspective-taking. Codes and categories were developed iteratively using NVivo, and earlier files reanalysed in the light of the developing framework. The initial coding was highly inductive, as we wished to ignore the argumentation categories captured by the quantitative analysis, to consider the knotting of perspective-taking and argumentation. The initial codes were collected into larger descriptive categories, which were then used to inform the research questions (Miles et al., 2020). The examples below are frequently not the best expressions of argumentation itself, showing rather how students drew upon different intellectual processes when responding to the scenarios. We followed British Educational Research Association's (2018) ethical guidelines, under formal university approval. Schools and students are anonymised, identified respectively below by letters and numbers. 


\section{Challenges to perspective-taking within argumentation}

Some students struggled with the process of perspective-taking within argumentation; answers were blank or with question marks, and so it is unclear why they were difficult. However, other students would explain why following someone else's reasoning was challenging. For example, in explaining Abdul's position in the Christmas scenario, one student wrote 'because it's his own opinion...so only he can decide his answer' (L22). Indeed, this student consistently held this position in that they maintained in the Zoo scenario that 'only [Ahmed] can decide his answer' (L22). For this student, an emic perspective was impossible; the characters had intellectual autonomy, and their claims and justifications were always their own to create, and the student could not be expected to enter into their thoughts: other minds were essentially unknowable.

Another example of the challenge was from a handful of students who were not prepared to take an emic stance but were prepared to judge the characters, taking an unsympathetic etic stance (see Fig. 1). The student jumps to an assessment of Olga's and Eve's intellectual virtues but does not present Olga's or Eve's evidence or justification. They have reached this judgement based on the scenario's details but were unwilling to explore these from the inside; capable of taking a normatively etic stance, they nevertheless lacked respect for the characters.

For others, emic perspective-taking was only possible within the limits set by the scenarios' wording. In the Zoo scenario (see "Appendix"), students were asked to decide whether two extra pieces of information - the inter-religious notion of stewardship and the zoos' potential educational value - could be used as further justification of one or both characters' arguments (questions e and f). The notion of stewardship could support both, and the suggestion that zoos had a potential educational benefit only supported Ahmed. Ahmed's and Charlotte's views of education or religion are not presented-we do not know what 'he' or 'she' thinks - so the questions require students to extend the line of argumentation beyond the limits of the character in the text, and so extrapolate that stewardship and the educative value of zoos are additional lines of evidence or warrant to support the explicit lines of evidence and warrant. Whilst most identified which character the new information supported, several held that the statements were irrelevant because the characters 'didn't mention religion' or 'didn't talk about education' (H13). For these students, their capacity to enter into the characters' perspectives was restricted to the explicit lines of justification, and to go beyond this was inappropriate.

This was more nuanced in recognising that at stake was whether the perspective-taking task - of assuming the character's identity-is paramount, in which case we do not know their actual views on these issues, or the articulation of an abstract argument, in which case supplementary evidence or warrant can be adopted and included. One student explained this hermeneutical challenge, indicating that extra information could support both one of

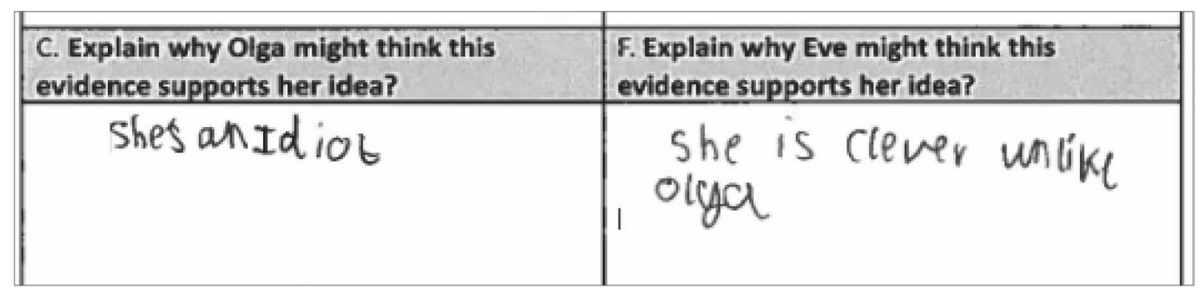

Fig. 1 Lack of respect (H20) 


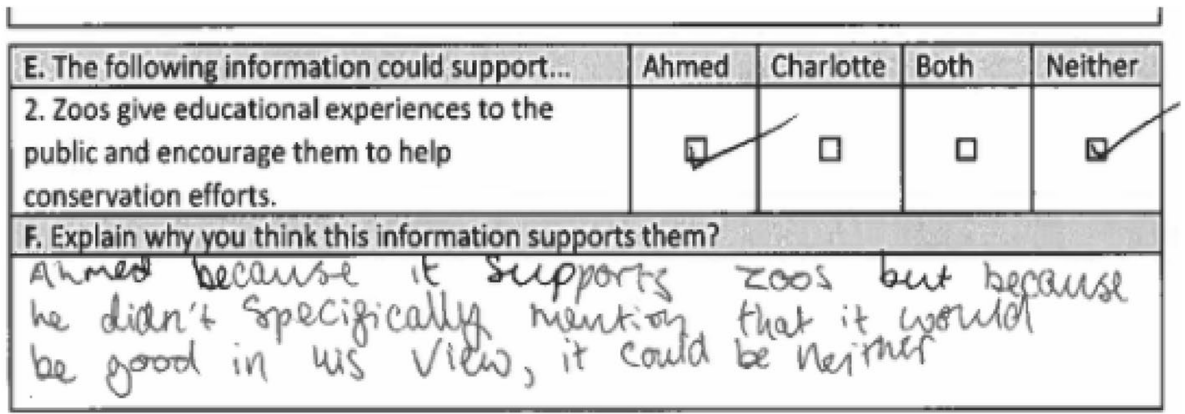

Fig. 2 The dilemma of different sets of rules of argumentation (L04)

the characters and neither of them (See Fig. 2). This student presents two options because they can see how a further line of justification might be provided for one character, but simultaneously that there is no explicit evidence for this line of argument within the initial scenario for either character; this was an example of a problematic answer for quantitative marking. If the task is to follow and develop supporting lines of argument out of the initial scenario, as a form of universal reasoning, then one approach applies, but if the task is to identify an individual's personal process, then another approach operates. The question could either purely be about Ahmed's thoughts, or it could be about the general argument in support of zoos, which Ahmed happens to present. Both strategies are possible, with the former favouring perspective-taking and the latter favouring universalist argumentation, and this student can explain the difficulty they face in having to choose: the challenge is in knowing which rules to adopt. This underscores the challenge for students when perspective-taking within argumentation-knowing when to move from perspective-taking of the characters to shared principles of reasoning. This is not so much about a move for the emic to the etic, but whether one can hypothesise on the basis of an assumed shared rationality.

Finally, some students combined this restriction on the emic with a normatively etic position seen previously. They were prepared to evaluate the characters' explicit arguments, but still not to follow through these new lines of justification. One student considered that the educational value of zoos supported neither because 'they both have positives and negatives, but they aren't talking of the educational side of things' (O19). This student felt confident enough to adjudge the overall merits of each character-though we do not know their reasons for this-and could understand what the characters lines of argument were, but they were unwilling to extend these arguments beyond the scenario.

\section{Strategies for perspective-taking within argumentation}

Mostly, students met the challenge of emic perspective-taking. The scenarios' most obvious feature was to enable students to trace the different characters' explicit lines of reasoning, to extend them, and then to go on judge them and formulate their own arguments. Students were required to explain the internal stages of each claim-even if they disagreed with it - to give an account of the character's own internal argument. Almost all were able to identify the relevant claims, evidence or warrant, but whereas some students would 
simply give the claim itself: 'that the stems are growing/there is no window' (L02), most would frame it as that person's opinion:

Because he's saying that he does not celebrate Christmas and no one except Christians should (W02, emphasis added)

And then also frame the other position:

...because she's saying everyone should as it would be unfair if one part of the family doesn't but the other does (W02, emphasis added)

A few students amended what they had initially written to reframe them as the characters' opinions: 'that this she knows it's a plant' - 'that she knows it's a fungus' (O50.) Here, the student shifts from 'that this is a plant' to 'that she knows it's a plant', putting a line through the word 'this', to present the two views in parallel according to their respective logics.

Also noticeable was an attentiveness to the scenarios' precise wording by using direct quotations:

Zoos, d: [Both] because Ahmed says it is "hard for wild animals to find their own food" suggesting if a zoo was open they could help animals live. And Charlotte says "it is cruel" suggesting she wants to help wildlife. W03.

This student sets out the two internal lines of argumentation, citing them equally. She presents the evidence before her. There is a fidelity to the characters' voices, in building up from the reported speech to their own summary interpretation. This fidelity might become a barrier to extending arguments beyond the scenario, outlined in the previous section, which the student circumvents by using 'suggesting', providing a gloss on the reported speech and so move toward the underlying processes of reasoning. This is a move from the emic to argumentation rather than to an etic position.

However, students were not always constant when they presented the characters' pointsof view, often using perspective-taking as a strategy for presenting a view with which they disagreed. A feature of many responses was to report the argument with which they disagreed as the character's opinion (e.g., 'Ahmed said...' or 'she saw...'), but simply to present directly the argument with which they agreed. Indeed, students would generally either present both as reported, or neither as reported, or the character they disagreed with as reported. There were almost no examples of reporting the argument with which they agreed but directly presenting the argument with which they disagreed. Figure 3 (overleaf) is an example from the Stems scenario, where the student disagreed with Olga and agreed with Eve. Olga's reasoning is framed as 'she saw' or 'she knew', whereas Eve's reasoning is unframed, and is also the student's own position, as shown in section G. For this student, Olga's position needs to be presented as reported speech, but Eve's approach is implicitly presented as being true so is not presented as being reported. Such answers assimilate one view with their own, implying its veracity, as against the strategy of reporting the incorrect view. The strategy allowed pupils to create some epistemic distance between themselves and the view they considered incorrect. The reporting device allows students to present an emic account of a view that they do not agree with, but its one-sidedness reveals a potential confirmation bias.

Further, characters started developing lives of their own. Students hypothesized family influences, notably in the Christmas scenario: 'Because [Miriams's] family might have that problem' (L21), or [Ahmed] 'was raised in a household that thinks that' (B03). These influences could be wider: 'Because people of [Ahmed's] religion might feel the same and think if you are not religious you should not celebrate.' (W11). These fictitious characters 


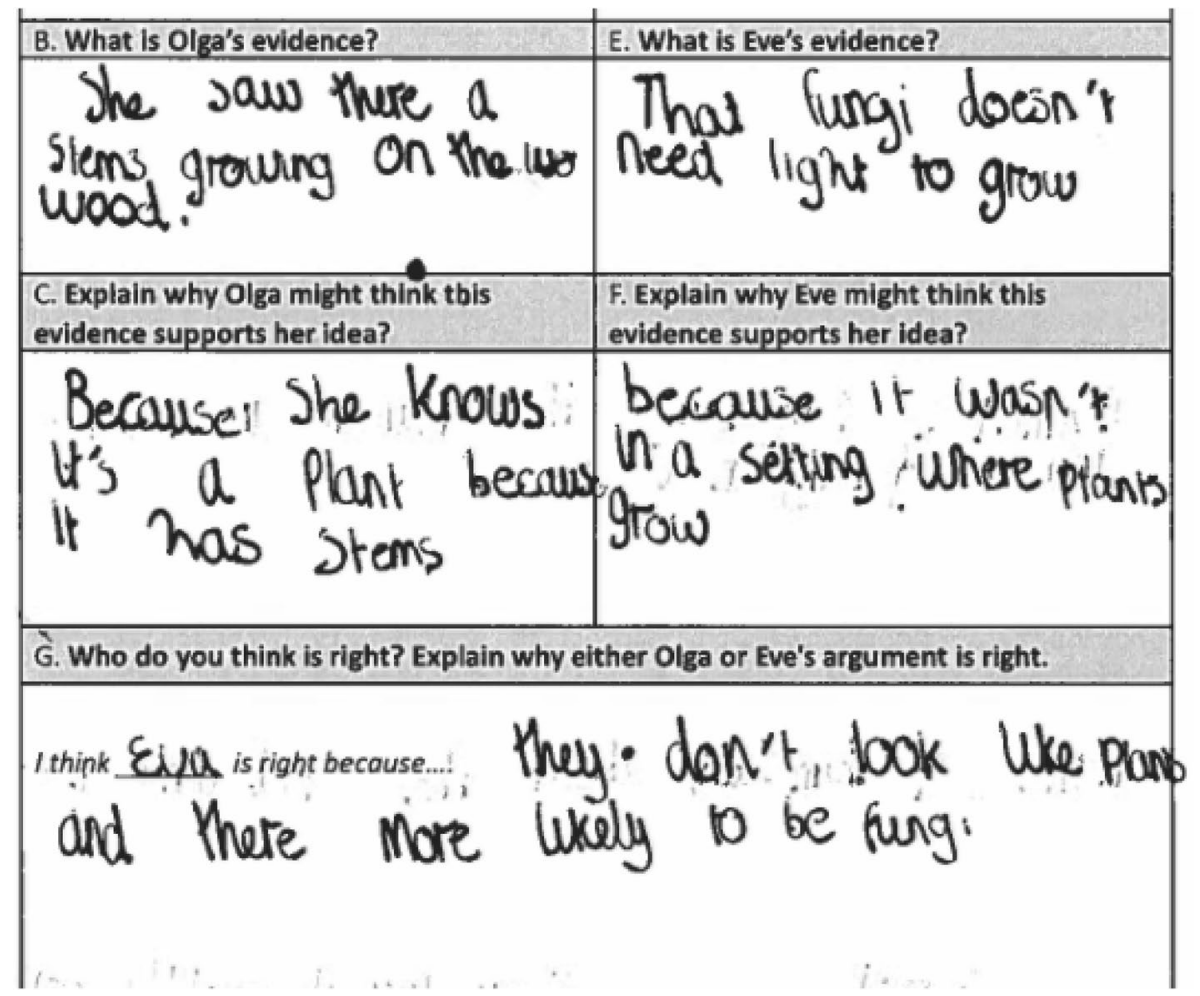

Fig. 3 Framing the 'incorrect' argument (W13)

were positioned within families or communities (the Ummah), to account for their claims. Indeed, a general principle could be applied to both; in the Christmas scenario, [Abdul] 'was raised in a house whole that thinks that...[Miriam] was also brought up in a house that thinks so' (L4). Home influence is presented as a generic explanation of anyone's views. These biographical speculations are both humane and reasonable etic accounts of why individuals hold particular beliefs. They are however not perspective-taking per se, since they would be unlikely to be the explicit reason that either character would give but are instead an explanation how those perspectives might come about. Neither are they argumentation per se, in that they do not refute or support the claims. Whilst this sort of point might be deployed rhetorically to challenge a claim-'you are only saying that because of your upbringing!' - the fact that here it applied to both characters as a general principle means it does not operate in this way, but rather as an inevitable factor shaping one's intellectual identity; it functions hermeneutically to explain why people's worldviews are often different. 


\section{Perspective-taking and personal argumentation}

The final question considers how students drew upon perspective-taking processes to develop and formulate their own positions. In all scenarios, the final question asked students with which of the two characters they agreed. The Stems scenario offered little room for alternative positions, and most students chose Eve over Olga, but the other two scenarios were more open-ended. Most students could at least give the name of the character with whom they agreed; some only provided this, but most would add their own explanation for agreeing with them.

First, unsurprisingly, students would stand outside the characters to comment on the quality of their argumentation, as an etic judgement. They suggested a wide range of qualities, including: evidence, 'Eve is right...because she gives me better evidence' (K01); research-based, '[Ahmed] has actually done some research' (L26); logic, 'Eve is right because it seems like a more logical answer...' (W16); accuracy, 'Eve is right because her evidence is more accurate' (W22); rightness, [Eve] has to be more right' (W22); applicability, 'Miriam's evidence applies to more people and in more varied contexts' (K07); correlation, 'The evidence correlates with her idea' (K06); justification, 'Olga's doesn't seem like that justifys that it's a plant' ((sic) L14); fullness, 'Abdul had the best, most fullest answer' (L21). These examples also show that many students considered these features to be gradable, given the frequent use of 'better', 'more' and 'most', which is particularly apparent in 'more right', since rightness is usually considered to be non-gradable. Such students grappled with expressing abstract senses of quality, especially as whilst they could articulate these judgements, they often failed to set out exactly what features of the arguments demonstrated them.

These criteria were neither universally agreed nor applicable to all scenarios; in Toulmin's terms these were field-dependent. In the Christmas scenario, students were divided over Ahmed's or Miriam's position was better or worse because it was more personal or impersonal. Some held that Ahmed's argument was better because 'it's his personal experience so people can understand where he is coming from' (W04), and contrastingly Miriam's was better 'because she makes it sound like fact by not using the first person' (O50) or 'she doesn't opinionate her argument, she doesn't use her personal preference as an argumental point' (K06). Conversely, they might prefer Miriam because hers was an 'emotional' reason (K06), or Ahmed's because 'he uses other religions to show that his statement isn't narrow' (O46). Moreover, these criteria might be scenario-specific: 'Abdul's argument is better because religion is a very personal thing and he is supporting that' (H27), which would be less likely to be held in the Stems scenario as botanical classification is not usually a personal thing. In considering religion and belief, the personal was a suitable criterion.

Third, each scenario's final question asked which character they considered to be right or have the better argument; the ability to grasp the two different arguments enabled many to incorporate a rebuttal of the other's point-of-view. Rebuttals could be explicit:

Eve because if it were to be a plant - Olga's idea would be wrong because Eve noticed that the shed has no window and so no light. That means that it couldn't be a plant because it wouldn't be possible to grow. On the other hand, Eve recalled that mushroom's also have stems too and this means that Olga might have just seen the stem. (H01) 
Here the student opens with a speculative subjunctive ('if it were...') then addresses Olga's points directly, following Eve's argument. This is essentially a paraphrased account of how Eve's argument rebuts Olga's, specifying what Eve 'saw' and 'recalled' and then adding a further biographical detail: perhaps Olga only saw the stem so that explains why she misread the situation. This student adopts a close emic analysis and biographical speculation and gives an etic judgement (Olga is 'wrong') to support their position.

Alternatively, they would raise new points to address or qualify the other point-of-view:

I think Miriam's argument is better because it applies to more people and on Abdul's argument, the religions might not mind sharing their holidays because they are still celebrating it. (O47)

This student seeks to accommodate Abdul's point by speculating that religions might adopt a more ecumenical view, which was not within the scenario itself. The potential for this point is implicit within the scenario since religiosity is a stated feature (unlike the education or stewardship examples), and the pupil expands on this as a potential ('might not mind') emic qualifier. Rebuttals could also be implicit, in that their points are addressed but individuals are unnamed. Here, Charlotte's argument against zoos is implicitly addressed:

I agree with Ahmed because we can breed animals while still leaving some in the wild to breed, therefore increasing the population. (W9)

We cannot tell for certain if this is intended to address Charlotte, but it echoes her words, so the perspective-taking elides into personal argumentation.

Finally, students would identify one argument as stronger, but nevertheless not agree with it, or at least not be prepared to reject the other claim. This could be made quite succinctly: on Christmas for non-Christians, one student considered that 'Abdul has a stronger point, but I agree with Miriam' (O64), or conversely, 'I'd say I agree with Miriam, but Abdul gave the best, most fullest answer' (L21). These students considered that the opposite view to theirs was better constructed, implicitly suggesting weaknesses in character's argument with which they agreed. A variation was 'I don't have an opinion on this, but I think that Abdul's argument is better as he gave the example of his faith and this holiday is similar to Christmas' (O94). Both these approaches might appear irrational, a stubborn form of cognitive bias, and it is unclear if this student considered that they had better arguments than those marshalled by the character whom they support, or if they simply did not want to change their position despite recognising the strength of the opposing argument. The lack of any further argumentation might suggest the latter, and this indicates the epistemic problem of deciding when to alter one's position in the light of conflicting evidence or argument. Indeed, the principles of argumentation might expect one to consider the layers of claim, evidence, warrant and backing, as well as potential rebuttals and qualifiers; perhaps one should not accept arguments on first encounter. The student here acknowledges the strength of Abdul's position, but holds it at a distance, as a puzzle, rather than accepting it personally outright.

The situation's potential complexity is shown when students do not simply choose between the two characters. For example, some might consider one claim to be better made, but still want to accept elements of both (Fig. 4, overleaf). This student positions themselves in the debate between the characters, and whilst holding that Eve's argument is right and more specific, also asserting that both are right. The argument is incoherent, but this stems from the struggle to express a nuanced balancing of the arguments and to find a middle ground. One may well applaud their aim of seeking a compromise even if it is argumentatively unsuccessful. 


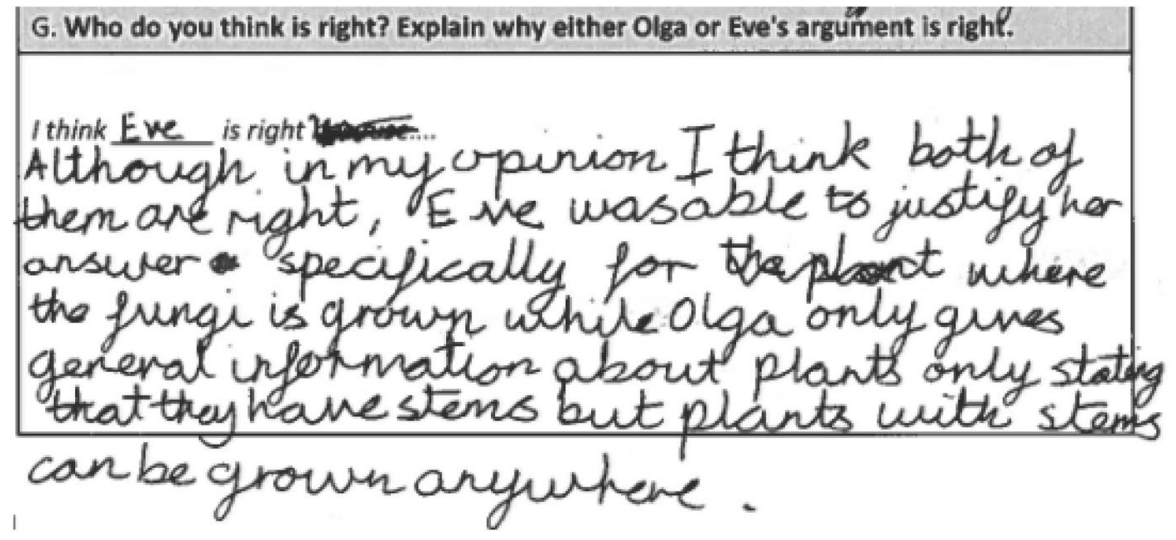

Fig. 4 Separation of agreement from strength of argument (K3)

\section{Discussion}

In considering how students approach perspective-taking within argumentation across religious education and science, the analysis showed on the one hand that this was not necessarily straightforward, and students might consider it impossible, limited or inappropriate, as further 'confirmation of the complexity' (Khan \& Zeitler, 2019, p. 631). On the other hand, others could also use it to present contradictory arguments and especially arguments which with they disagreed-elements which previous research had suggested was challenging (e.g., Chinn \& Brewer, 1993)- as well as to build up their own position by positioning themselves in relation to these perspectives. From this balance, five broad points can be drawn.

First, perspective-taking can contribute much to the development of pupils' skill in argumentation across different subjects, but this process is neither straightforward nor undemanding. Perspective-taking is itself a complex intellectual act, requiring the suspension of the student's own judgement—bracketing out-and then the emic tracing of the other thoughts sensitively and empathetically (Smart, 1969; Khan \& Zeidler, 2019). Some students struggled, lacking the respect demanded. Others attempted perspective-taking but considered that there were conceptual limits or ambiguities in extending or developing the arguments of others. Some went on to provide a descriptive etic overview or rationalisation. Then, they might apply an etic judgement before giving their application of reasoned judgement in order to give their own position on the situation. The research captures how students were doing what we all must do, which is to balance our engagement with the arguments of others with the formulation of our own arguments. Khan \& Zeidler (2019) highlight the necessity of moving from an etic position to an emic one in perspective-taking in socio-scientific issues. However, the next challenge is to return to an informed etic position to formulate their own claims, and the third is to do this normatively as well as descriptively (Weiss, 2016). Students need to refine the capacity to provide generic explanation of the perspectives e.g., from biography, family or community, and then to take a 
stance themselves, whether in support of the characters or in finding a nuanced alternative or middle ground.

There are also implications for each subject independently. In pluralistic religious education and research, greater attention to the place of perspective-taking within argumentation could resolve the tension between ensuring that students understand a range of religions and worldviews impartially, through in-depth perspective-taking, and encouraging pupils to present their own normative views on theological, philosophical and ethical issues (Chan et al., 2020). The move from the etic to the emic and back again is critical here, but under-theorised and under-researched (though see Jackson, 1997; Fancourt 2014). Further, perspective-taking within argumentation may also have a role to play within more faith-based models of the subject, for example in the German-speaking world, where argumentation is a focus of much research already (Fuchs, 2009; Weiss, 2016).

In science education research, the value of perspective-taking has been emphasized within socio-scientific issues, but the example here shows its role within the more conventional curriculum. Even the most basic claims around the interpretation of data and scientific classification offer the potential for perspective-taking, and the development in these domains may support its application in socio-scientific issues, rather than assuming that perspective-taking is restricted to these issues alone (see Khan \& Zeidler, 2019), where it might appear out of place. More complex versions of the Stems scenario with less clarity and alternative layers of evidence could demand more nuanced reasoning, so that the solution was more debatable. Perspective-taking is of value in both epistemic and ethical issues - and when they combine-and in order to enable student to deploy perspectivetaking on issues such as climate change or nuclear power, it would be sensible to have built up their capabilities beforehand.

Fourth, building in the previous points that perspective-taking within argumentation is epistemic and ethical, and operates across science and religious education, it is well placed to enable students to engage in debates about the relationship between sciences and religions (Hoven, 2015). It is striking how the same features can be found across the different scenarios. Students did not treat the characters in the Stems scenario differently to the Christmas scenario, or the Zoo scenario. The same movement between the emic, the etic and personal argumentation could be seen in them all, with similar approaches and challenges, which has implications for developing effective strategies for addressing how sciences, religions and worldviews interrelate. Perspective-taking requires students to be both more attentive to individual claims made, and to be slower to judge them, and this more empathetic and deliberative demand may potentially circumvent student perceptions of a divide (Billingsley et al., 2012; Pearce et al., 2019). This however is not at the expense of critique; perspective-taking within argumentation means that entering into the perspectives of others will also give students' insights into potential points of weakness. The strategy here is not to attempt to resolve an intellectual debate, but to allow pupils to enter into the debate more fully and thoughtfully - though clearly opportunities for this may be constrained by constitutional positions in some countries.

Finally, our research shows the value of these strategies for students, especially in learning the skills of argumentation, and we do not consider them to be simply a stage in the development of formal abstract thought (contra Kuhn, 1991). Wider hermeneutical principles are at stake, and debates about the nature of argumentation in a post-secular society 
(Franck \& Thalén, 2021). At its most basic, perspective-taking can serve as a useful pedagogical device to engage in argumentation because it supports students' understanding of the fundamentals of argumentation, notably the chain of claim, evidence and warrant, but it can also situate those fundamentals within an appreciation of the lived experiences of others, and how arguments are simultaneously personal and universal. On the one hand, it is useful to pay attention to both typologies of argumentation and the specificities of disciplines, but on the other students will both come at these issues by drawing on a range of approaches to perspective-taking and will need support in doing so effectively for public scrutiny.

\section{Conclusion}

Olga never saw any stems, Abdul celebrates neither Eid nor Christmas, and Charlotte does not care about animals because none of them exist. They were fictions for research purposes, but beyond meagre lines of text they came to argue directly with each other, to have families and communities, and to be adjudged. What they share is being the banal device of presenting different characters as the voices of different lines of argument, a commonplace in school textbooks and tasks, but which generated a wealth of responses, illustrating students' different challenges and approaches.

One distinctive feature of this project is the students' ages, between 11 and 14 years old, since much research on perspective-taking and argumentation is with college students or undergraduates, who have already been through much of their schooling, and often have decided to specialise in one subject. Research on socio-scientific issues tends to draw on science students, who are by then products of a particular approach to different subjects within the school curriculum, and different approaches to both perspective-taking and argumentation. There is an intriguing question as to whether these undergraduates were not offered the opportunity to develop their perspective-taking skills during their schooling, which is why they struggle with it now. This itself leads onto an even wider question about the development of other cross-curricular work on the value of perspective-taking for these purposes, and how a more integrated approach across the curriculum would more fully enable students to engage in humane, deliberative, critical debate. Unfortunately, opportunities for school students to develop these capabilities in relation to scientific, religious and ethical questions can be constrained by constitutional arrangements, but there would undoubtedly be other possibilities across the rest of the curriculum too. 


\section{Appendix 1: Completed research instrument[W3]}

\section{A Zoo Near You?}

Suppose you heard that the local council is considering opening a zoo. The council would like to know the public's opinion about this. Some people believe that zoos should be banned. Others think that zoos serve a good role in our society. Ahmed and Charlotte are discussing whether a zoo should be developed or not.
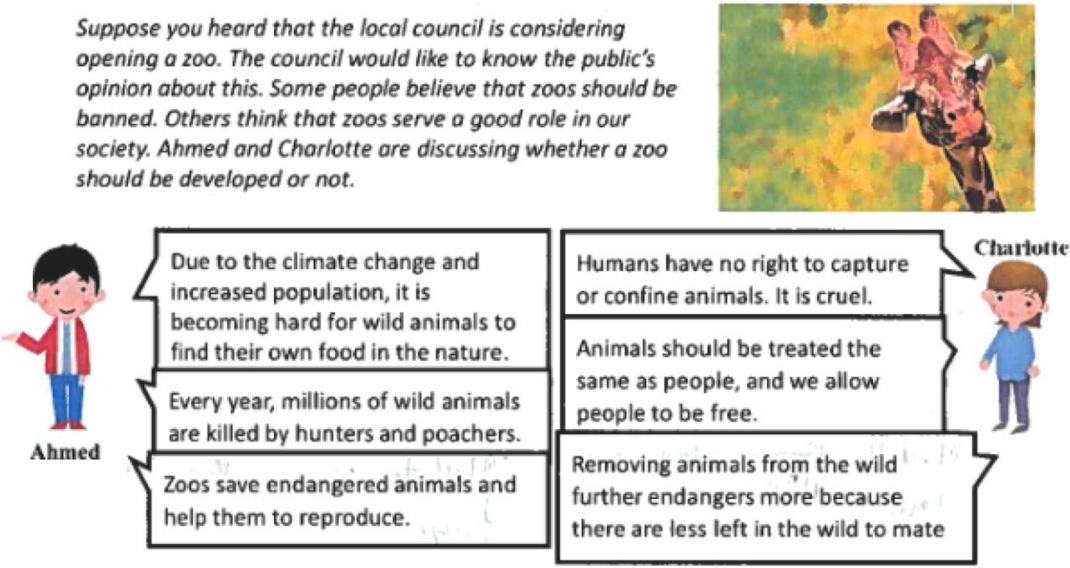

\begin{tabular}{|l|l|}
\hline $\begin{array}{l}\text { A. Which Idea do you think Ahmed } \\
\text { supports? }\end{array}$ & $\begin{array}{l}\text { B. Which idea do you think Charlotte } \\
\text { Supports? }\end{array}$ \\
\hline $\begin{array}{l}\text { Th That a zoo should be built. } \\
\square \quad \text { That a zoo should NOT be built. }\end{array}$ & $\square /$ That a zoo should be built. \\
That a zoo should NOT be built. \\
\hline
\end{tabular}

\begin{tabular}{|l|l|l|l|l|}
\hline C. The following information could support... & Ahmed & Charlotte & Both & Neither \\
\hline
\end{tabular} 1. Many religions suggest that humans should be stewards of all life.

\begin{tabular}{|c|c|c|c|}
\hline Ahmeg & Charlotte & Both & Neither \\
\hline & $\square$ & $\checkmark$ & $\square$
\end{tabular}

D. Explain why you think this information supports them?

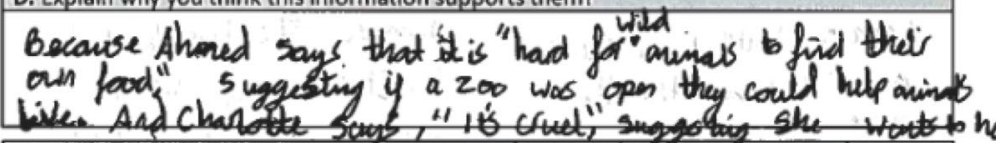
\begin{tabular}{|l|l|l|l|l|}
\hline E. The following information could support... & Ahmed & Charlotte & Both & Neither \\
\hline 2. Zoos give educational experiences to the & & &
\end{tabular} public and encourage them to help conservation efforts.

F. Explain why you think this information supports them?

\section{Becauce thust cone of then mertion education}

G. Who do you agree with? Why do you agree with them?

I agree with Ahned because zoos help endargered arimals stell be seen and childres con see cuinals that may be
exctict in the wild. 


\section{What's Growing?}

Olgo and Eve found something growing on some wood inside the garden shed (see picture on the right). They wondered "what are these growing things?".

Olga noticed there are stems growing from the wood and she says that they must be plants because she knows plants have stems.

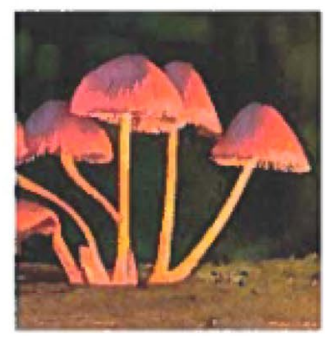

Eve noticed that the shed has no window and so no light. She says these growing things must be fungus because she knows plants need light to grow but fungi do not. Also, it looks a little like the mushrooms she eots. Eve recalled mushrooms are fungi and have stems too.

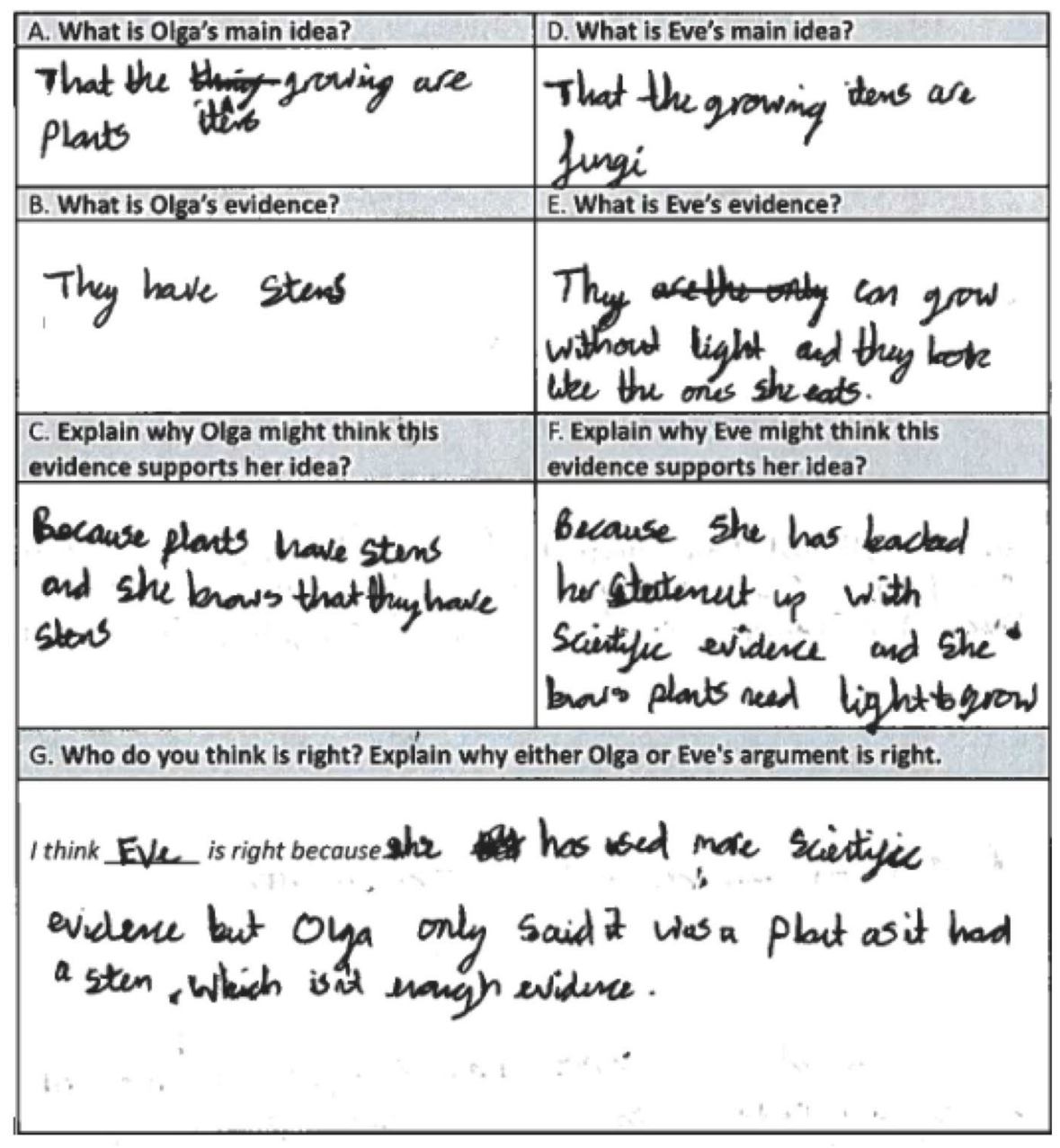




\section{Christmas for non-Christians?}

Some people say that anly Christians should be allowed time off work and school ot Christmas.

Others disagree, saying that anyone should be allowed to celebrate it and have time off.
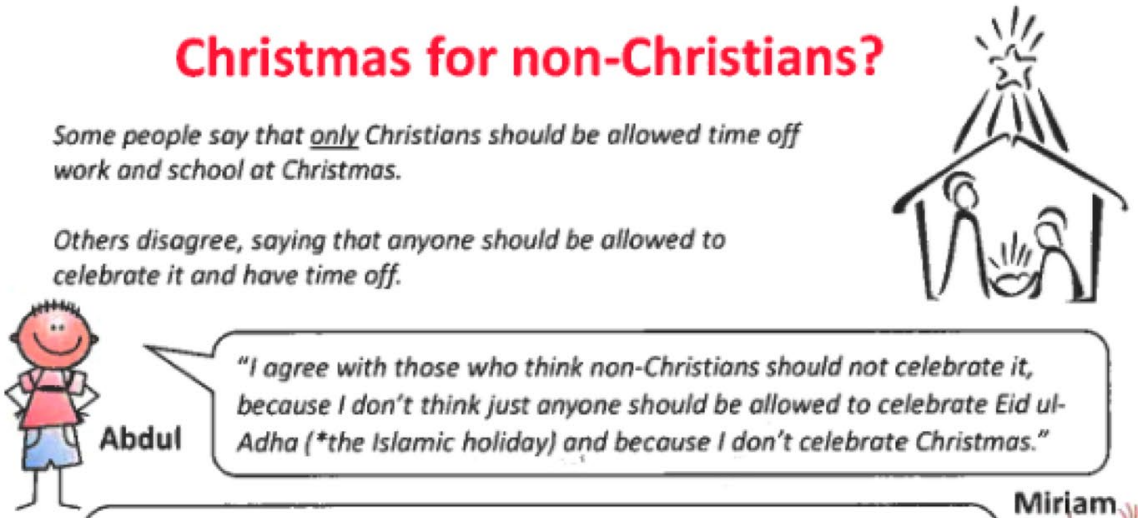

"f agree with those who think non-Christions should not celebrate it, because I don't think just anyone should be allowed to celebrate Eid ul-

Abdul Adha ("the Islamic holiday) and because I don't celebrate Christmas."

"There are families where not everyone is of the same faith; some are Christians and others have different faiths or none. It would not be foir to split these families apart during Christmas by giving only some of them time-off."

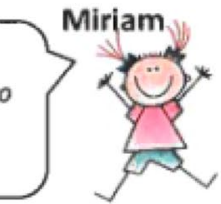

\begin{tabular}{|l|l|}
\hline $\begin{array}{l}\text { A. What is Abdul's position? (Choose one) } \\
\text { That non-Christians should not be } \\
\text { allowed to celebrate Christmas } \\
\text { That Muslims should be allowed to } \\
\text { celebrate Eid ul-Adha }\end{array}$ & $\begin{array}{l}\text { D. What do you think is Miriam's position? } \\
\text { (Choose one) }\end{array}$ \\
$\begin{array}{l}\text { That he does not celebrate Christmas } \\
\text { Thans. }\end{array}$ & That Christmas should be for anyone.
\end{tabular}

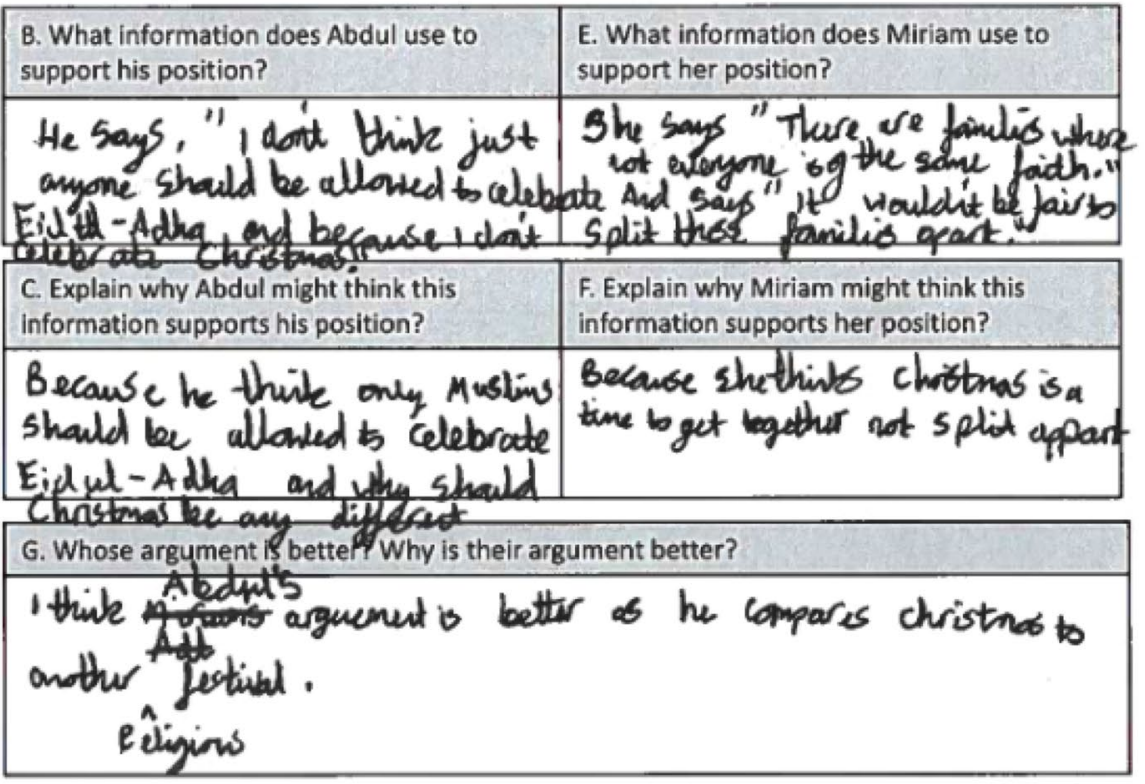


Author contributions NF analysed the data and wrote the text. LG is project officer for the OARS Project (see Funding), conducted the school-based research and edited the text.

Funding The authors acknowledge funding from the Templeton World Charity Foundation for the OARS Project [Grant No. TWCF0238].

Data availability Data and materials are confidential and stored in line with the ethics approval set out below.

\section{Declarations}

Conflict of interest There are no conflicts of interest.

Ethical approval From Departmental Research Ethics Committee (DREC), Department of Education, University of Oxford under Central University Research Ethics Committee (CUREC) procedures, and following BERA guidelines.

Informed Consent Guardians' and students' consents were obtained under CUREC procedures.

Open Access This article is licensed under a Creative Commons Attribution 4.0 International License, which permits use, sharing, adaptation, distribution and reproduction in any medium or format, as long as you give appropriate credit to the original author(s) and the source, provide a link to the Creative Commons licence, and indicate if changes were made. The images or other third party material in this article are included in the article's Creative Commons licence, unless indicated otherwise in a credit line to the material. If material is not included in the article's Creative Commons licence and your intended use is not permitted by statutory regulation or exceeds the permitted use, you will need to obtain permission directly from the copyright holder. To view a copy of this licence, visit http://creativecommons.org/licenses/by/4.0/.

\section{References}

Acar, O., Turkmen, L., \& Roychoudhury, A. (2010). Student difficulties in socio-scientific argumentation and decision-making research findings: Crossing the borders of two research lines. International Journal of Science Education, 32(9), 1191-1206. https://doi.org/10.1080/09500690902991805

Altmeyer, S. (2021). Religious education for ecological sustainability: An initial reality check using the example of everyday decision-making. Journal of Religious Education, 69, 57-74. https://doi.org/10. 1007/s40839-020-00131-5

Basel, N., Harms, U. \& Prechtl, H. (2013). Analysis of students' arguments on evolutionary theory. Journal of Biological Education., 47(4), 192-199. https://doi.org/10.1080/00219266.2013.799078

Basel, N., Harms, U., Prechtl, H., Weiß, T., \& Rothgangel, M. (2014). Students' arguments on the science and religion issue: The example of evolutionary theory and genesis. Journal of Biological Education, 48(4), 179-187. https://doi.org/10.1080/00219266.2013.849286

Belova, N., Eilks, I., \& Feierabend, T. (2015). The evaluation of role-playing in the context of teaching climate change. International Journal of Science and Mathematics Education, 13, 165-190. https://doi. org/10.1007/s10763-013-9477-x

Billingsley, B., Taber, K., Riga, F., \& Newdick, H. (2012). Secondary school students' epistemic insight into the relationships between science and religion-a preliminary enquiry. Research in Science Education, 43, 1715-1732. https://doi.org/10.1007/s11165-012-9317-y

British Educational Research Association [BERA]. (2018). Ethical Guidelines for Educational Research (4th ed.). BERA.

Chan, J., Fancourt, N., \& Guilfoyle, L. (2020). Argumentation in religious education in England: An analysis of locally agreed syllabuses. British Journal of Religious Education. https://doi.org/10.1080/01416 200.2020.1734916.

Chinn, C. A., \& Brewer, W. F. (1993). The role of anomalous data in knowledge acquisition: A theoretical framework and implications for science instruction. Review of Educational Research, 63(1), 1-49. https://doi.org/10.3102/00346543063001001 
Coleridge, S. (1985). Biographia literaria. In H. Jackson (Ed.), Samuel Taylor Coleridge. The major works (pp. 157-482). Oxford: Oxford University Press.

Dawkins, R. (2006). The god delusion. Bantam Press.

Dodick, J., Dayan, A., \& Orion, N. (2010). Philosophical approaches of Religious Jewish Science teachers toward the teaching of 'controversial' topics in science. International Journal of Science Education, 32(11), 1521-1548. https://doi.org/10.1080/09500690903518060

Duveen, J., \& Solomon, J. (2007). The great evolution trial: Use of role-play in the classroom. Journal of Research in Science Teaching, 31, 575-582. https://doi.org/10.1002/tea.3660310510

Endacott, J. (2014). Negotiating the process of historical empathy. Theory \& Research in Social Education, 42(1), 4-34. https://doi.org/10.1080/00933104.2013.826158

Erduran, S. (2020). Argumentation in science and religion: Match and/or mismatch when applied in teaching and learning? Journal for Education for Teaching, 46(1), 129-131. https://doi.org/10.1080/02607 476.2019.1708624

Erduran, S., Simon, S., \& Osborne, J. (2004). TAPping into argumentation: Developments in the application of Toulmin's argument pattern for studying science discourse. Science Education, 88(6), 915-933. https://doi.org/10.1002/sce.20012

Erduran, S., Guilfoyle, L., Park, W. Chan J \& Fancourt N. (2019). Argumentation and interdisciplinarity:reflections from the Oxford Argumentation in Religion and Science Project. Disciplinary andInterdisciplinary Science Education Research 1, 8. https://doi.org/10.1186/ s43031-019-0006-9

Fancourt, N. (2014). Insiders and outsiders: Task design in learning about religions. In I. Thompson (Ed.), Designing tasks in secondary education enhancing subject understanding and student engagement (pp. 170-188). London: Routledge.

Franck, O., \& Thalén, P. (Eds.). (2021R). Religious education in a post-secular age. Palgrave.

Franken, L., \& Loobuyck, P. (2011). Religious education in a plural, secularised society: A paradigm shift. Waxmann.

Freathy, R., \& John, H. (2019). Religious Education, Big Ideas and the study of religion(s) and worldview(s). British Journal of Religious Education, 41(1), 27-40. https://doi.org/10.1080/01416200.2018.15003 51.

Fuchs, M. E. (2009). Empirische Und Didaktische Perspektiven Bioethischen Lernens Im Religionsunterricht [Empirical and Didactical Perspectives of Bioethical Learning in Religious Education]. TheoWeb. Zeitschrift Für Religionspädagogik [theo-Web. Journal for Religious Education], 8(1), 80-90.

Gadamer, H.-G. (2004). Truth and method (2nd, rev. ed.) London: Continuum.

Gallagher, K., \& Booth, D. (Eds.). (2018). How theatre educates. University of Toronto Press. https://doi. org/10.3138/9781442627574

Guilfoyle, L., Erduran, S., \& Park, W. (2020). An investigation into secondary teachers' views of argumentation in science and religious education. Journal of Beliefs \& Values. https://doi.org/10.1080/13617 672.2020.1805925.

Guilfoyle, L, Hillier, J., \& Fancourt, N. (2021). Students' argumentation in the contexts of science, religious education, and interdisciplinary science-religious education scenarios. Research in Science \& Technological Education. https://doi.org/10.1080/02635143.2021.1947223.

Hanley, P., Bennett, J., \& Ratcliffe, M. (2014). The Inter-relationship of Science and Religion: A typology of engagement. International Journal of Science Education, 36(7), 1210-1229. https://doi.org/10. 1080/09500693.2013.853897

Hoven, M. (2015). Teaching creation: Ancient belief meets modern science. Journal of Religious Education, 63, 1-12. https://doi.org/10.1007/s40839-015-0014-9

Husserl, E. (1931). Ideas: General introduction to pure phenomenology. [Trans. Ideen zu einer reinen Phänomenologie und phänomenologischen Philosophie]. Routledge.

Jackson, R. (1997). Religious education: An Interpretive approach. Hodder and Stoughton.

Jackson, R. (2014). Signposts-Policy and practice for teaching about religions and non-religious world views in intercultural education. Council of Europe.

Jackson, R., \& Everington, J. (2017). Teaching inclusive religious education impartially: An English perspective. British Journal of Religious Education, 39(1), 7-24. https://doi.org/10.1080/01416200.2016. 1165184

Kahn, S., \& Zeidler, D. L. (2016). Using our Heads and HARTSS*: Developing perspective-taking skills for socioscientific reasoning (*Humanities, ARTs, and Social Sciences). Journal of Science Teacher Education, 27(3), 261-281. https://doi.org/10.1007/s10972-016-9458-3

Kahn, S., \& Zeidler, D. L. (2019). A conceptual analysis of perspective taking in support of socioscientific reasoning. Science \& Education, 28, 605-638. https://doi.org/10.1007/s11191-019-00044-2 
Kelly, G. J., \& Chen, C. (1999). The sound of music: Constructing science as sociocultural practices through oral and written discourse. Journal of Research in Science Teaching, 36, 883-915. https://doi.org/10. 1002/(SICI)1098-2736(199910)36:8\%3c883::AID-TEA1\%3e3.0.CO;2-I

Kerdeman, D. (2015). Interpretation, social science and educational research. In P. Smeyers, D. Bridges, N. Burbules, \& M. Griffiths (Eds.), International Handbook of Interpretation in Educational Research (Vol. 1, pp. 17-38). Springer.

Kuhn, D. (1991). The skills of argument. Cambridge University Press.

Lee, P., \& Ashby, R. (2001). Empathy, perspective taking, and rational understanding. In O. L. Davis, E. A. Yeager, \& S. J. Foster (Eds.), Historical empathy and perspective taking in the social studies (pp. 21-50). Rowman \& Littlefield Publishers.

Mahner, M., \& Bunge, M. (1996). Is religious education compatible with science education? Science \& Education, 5(2), 101-123. https://doi.org/10.1007/BF00428612

Maniatakou, A., Papassideri, I., \& Georgiou, M. (2020). Role-play activities as a framework for developing argumentation skills on biological issues in secondary education. American Journal of Educational Research, 8(1), 7-15. https://doi.org/10.12691/education-8-1-2

McCrudden, M., Barnes, A., McTigue, E., Welch, C., \& MacDonald, E. (2016). The effect of perspectivetaking on reasoning about strong and weak belief-relevant arguments. Thinking \& Reasoning, 23(2), 1-19. https://doi.org/10.1080/13546783.2016.1234411

Miles, M., Huberman, A., \& Saldaña, J. (2020). Qualitative data analysis: A methods sourcebook (4th ed.). Sage.

Ministry of Education Science and Technology. (2008). The school curriculum of the Republic of Korea. Ministry of Education, Science and Technology.

Morrison, K. (1988). I am you: The Hermeneutics of empathy in Western literature, theology, and art. Princeton University Press.

Newton, M., \& Zeidler, D. L. (2020). Developing socioscientific perspective taking. International Journal of Science Education, 42(8), 1302-1319. https://doi.org/10.1080/09500693.2020.1756515

Nussbaum, M. (2010). Not for profit: Why democracy needs the humanities. Princeton.

Oancea, A., \& Pring, R. (2008). The importance of being thorough: On systematic accumulations of 'what works' in education research. Journal of Philosophy of Education, 42, 15-39. https://doi.org/10.1111/j. 1467-9752.2008.00633.x

O'Grady, K. (2018). Religious education as a dialogue with difference: Fostering democratic citizenship through the study of religions in schools. Routledge.

Osborne, J. F., Henderson, J. B., MacPherson, A., Szu, E., Wild, A., \& Yao, S.-Y. (2016). The development and validation of a learning progression for argumentation in science. Journal of Research in Science Teaching, 53(6), 821-846. https://doi.org/10.1002/tea.21316

Pearce, J., Stones, A., Reiss, M., \& Mujtaba, T. (2019). 'Science is purely about the truth so I don't think you could compare it to non-truth versus the truth'. Students' perceptions of religion and science, and the relationship(s) between them: religious education and the need for epistemic literacy. British Journal of Religious Education. https://doi.org/10.1080/01416200.2019.1635434

Pizarro, D., Detweiler-Bedell, B., \& Bloom, P. (2006). The creativity of everyday moral reasoning: empathy, disgust, and moral persuasion. In J. Kaufman \& J. Baer (Eds.), Creativity and reason in cognitive development (pp. 81-98). Cambridge University Press. https://doi.org/10.1017/CBO9780511606915. 006

Roughley, N., \& Schramme, T. (Eds.). (2018). Forms of fellow feeling: Empathy, sympathy, concern and moral agency. Cambridge University Press.

Scheler, M. (1954). The Nature of Sympathy (5th ed.). Transl. by P. Heath. Routledge and Kegan Paul

Schleiermacher, F. (1977). Hermeneutics: The handwritten manuscripts. Scholars Press.

Schools Council. (1971). Religious education in secondary schools. Methuen International.

Simmoneaux, L. (2007). Argumentation in socio-scientific contexts. In S. Erduran \& M. P. Jiménez-Aleixandre (Eds.), Argumentation in science education (pp. 179-200). Springer.

Skolverket. (2018). Curriculum for the compulsory school, preschool class and school-age educare. Revised 2018. Stockholm: Skolverket [English version]. Retrieved from https://www.skolverket.se/download/ 18.6bfaca41169863e6a65d4df/155.

Smart, N. (1969). The religious experience of mankind. Prentice Hall.

Taber, K. S., Billingsley, B., Riga, F., \& Newdick, H. (2011). Secondary students' responses to perceptions of the relationship between science and religion: Stances identified from an interview study. Science Education, 95(6), 1000-1025. https://doi.org/10.1002/sce.20459

Toulmin, S. (1958). Uses of argument. Cambridge University Press.

van Eemeren, F. (2010). Strategic Maneuvering in Argumentative Discourse: Extending the pragma-dialectical theory of argumentation. John Benjamins Publishing Company. 
Walton, D. (1996). Argumentation schemes for presumptive reasoning. Erlbaum.

Weiß, T. (2016). Fachspezifische und fachübergreifende Argumentationen am Beispiel von Schöpfung und Evolution. [Disciplinary and multidisciplinary arguments using the example of creation and evolution]. V\&A.

Wright, A. (1993). Religious education in the secondary school: Prospects for religious literacy. David Fulton.

Zeidler, D. L. (Ed.). (2003). The role of moral reasoning on socio-scientific issues and discourse in science education. Kluwer.

Publisher's Note Springer Nature remains neutral with regard to jurisdictional claims in published maps and institutional affiliations. 